\title{
Justification of Domestic Violence by Mexican Women
}

\author{
Gloria Gurrola Margarita Peña, \\ Patricia Nava Balcazar \\ National Autonomus University of \\ Mexico, Mexico, Mexico
}

\author{
Eugenio Esteban Esquivel \\ Santoveña \\ University of Birmingham, \\ Birmingham, UK
}

\author{
Alejandra Moysen Chimal, Juana \\ Maria Esteban Valdes, Julieta \\ Garay Lopez \\ National Autonomus University of \\ Mexico, Mexico, Mexico
}

\begin{abstract}
The main objective of this study is to determine the construction that women living in intimate violent partner relationship make about the reasons that men exercise on them. The research involved 30 women that have voluntarily attended counseling services at the victims of crime area, of which the Attorney General of the State of Mexico's office is in charge. The data collection techniques used were the autobiography and in-depth interviews. For the analysis of results, qualitative content analysis was used. The results indicate that women consider that the violence they suffer from their partners is mainly caused by the consumption of alcohol, violence learned and suffered at home, prevalence of machismo, as well as certain psychological and physiological problems present at everyday life. In addition, reasons for violence and attacks on women include a poor performance of the work of women in their role as housewives, being self-sufficient and making their own decisions and the very spouse's family. The authors infer that these two groups of conclusions tend to remove responsibility on partners that usually exercise violence on their wives, induce the idea that this problem is externally caused and that there is not any culpability on men. Moreover, the explanation includes conscious intentions and willingness to discipline females directly associated with the abuse over women due to the culturally and socially established roles.
\end{abstract}

Keywords: domestic violence, women, constructivism

\section{Introduction}

Today, cases of women who experience violence in their relationships are particularly relevant because of the frequency registered and due to the physical and emotional damage produced. In accordance to the World Health Organization (2002), 10\%-69\% of women have been physically assaulted by their partners at some point in the relationship. In Mexico, it is found that 25.8\% of users of health services in 2003 had experienced some form of aggression from their partners in the past 12 months (INSP (Instituto Nacional de Salud Pública), 2003), an indicator that unfortunately compares with the 33.3\% level recorded in 2006 (INSP, 2006), jumping eight basis points in the three-year period.

Physical violence on women is easy to identify considering its own visibility. However, many signs and

Gloria Gurrola Margarita Peña, Ph.D., professor, National Autonomus University of Mexico.

Patricia Nava Balcazar, Ph.D., professor, National Autonomus University of Mexico.

Eugenio Esteban Esquivel Santoveña, Ph.D. candidate, assistant professor, University of Birmingham.

Alejandra Moysen Chimal, Ph.D., professor, National Autonomus University of Mexico.

Juana Maria Esteban Valdes, M.A., professor, National Autonomus University of Mexico.

Julieta Garay Lopez, Ph.D., professor, National Autonomus University of Mexico. 
symptoms of emotional distress are linked to other types of aggressive behavior and control that men exercise over women, of sexual, psychological, and economic nature. Despite the fact that domestic violence is an important concern which has gained ground recently, it is identified as a personal, social, and cultural taboo. For these reasons, violence against women by their partners must be understood in its own context, which also involves daily interaction and a broader set of relationships with the social environment. Thus, concealment, naturalization, and denial begin to take place.

In this regard, Lorente (2001) explained that in the case of women that experience a first attack of domestic violence, there is a tendency to think about a non-existence reason for that considering their own inner world full of doubts, unanswered questions, and pain. Conversely, their family only provides unjustifiable premises and explanations to the attack suffered, plenty fulfilled with erroneous reasons that do not blame men (i.e., "be patient, he will change, accept your destiny"). When subsequent attacks take place, doubts tend to disappear but they do not change, however. Thoughts are no longer focused on whether the aggression is right or wrong, but whether the motive was sufficient or not. With the passage of time, concerns are no longer about whether violence is right or wrong, or even if reasons are justified or not. On the contrary, now doubts are whether the fault was on the couple or was the female who led to aggression itself. Again, the arguments, justifications, and explanations make it clear that it was her fault for provoking the husband, therefore, they construct the meaning of the violence females suffer within their relationship. Consistent with the above mentioned, it was found that a larger number of women living in violent relationship do not perceive their relationship as problematic. Therefore, they attribute the cause of the attacks on a great array of factors, including the consumption of alcohol by their partner, frustration, and stress in daily life and may even blame themselves for bad behavior. In the end, women do not fully recognize the deliberate intention of the aggressor (Babcock, Jacobson, Gottman, \& Yerington, 2000).

The perception of causes and reasons involved seems to be the focal point for women to explain why they do tolerate aggression by their partners. In this regard, the National Survey on Violence Against Women (INSP, 2003) conducted in Mexico, provided qualitative analysis which led to the disciplinary reasons to explain conscious intentions and willingness to abuse by the perpetrator, while the causes of violence respond to an external origin beyond the control of the violent man. Hamel, Desmarais, and Nicholls (2007) referred to these aspects when talking about coercive or intentional violence reported by offenders whose motivation is rooted in the desire to control and impose their authority and ensure that their partners listen and meet their needs. Expressive violence, on the other hand, is caused by the desire to express anger which has been accumulated over their lives due to in tolerance or early experiences of everyday pressures.

Regardless of the terms used, it is important to note how the meaning of partner violence is constructed from the point of view of women who deny the aggressor's responsibility with an increasing sense of blame on females themselves. This circumstance is explained by Richie (1996) under the term "gender incitement", whereas the women respond to socially established expectations about the behavior of women in their marital relationship. That is primarily determined by the fact that females are responsible for maintaining harmony at the household as their cultural and social roles ordinarily establish.

That is the objective of the study: To determine the construction that women living in couples made about the reasons of violence caused on them by partners. 


\section{Method}

\section{Participants}

A group of 30 women collaborated on the study. Their ages ranged from 26 to 41 . They attend the Psychological Services Unit for Victims of Crime of the Attorney General of the State of Mexico's office. Important to mention is the fact that participants have experienced marital violence during nine years on an average basis.

\section{Techniques}

The techniques are as follows:

(1) Autobiography: It corresponds to the account of a person's life written by herself;

(2) Depth interview: It refers to repeated face to face meetings between the researcher and informants in order to look into the perspectives, the informants have developed about their lives, experiences or situations as these are expressed in their own words.

\section{Lines of Analysis}

The lines of analysis are:

(1) Causes: Women tend to attribute reasons of external nature, and beyond the control of man's abuse;

(2) Reasons: Women refer to conscious intentions and willingness to partner's abuse to discipline and keep women in socially established gender role.

\section{Procedure}

In order to initiate the study, contact was established with the Attorney General of the State of Mexico's office, specifically through the Services Unit for Victims of Crime. Once, work was authorized and participants agreed to collaborate, researchers proceeded to get in touch with women who still remained in relation of violence and who came to the center for counseling. During the first session, participants were asked to write their own biography in free style. In the following two sessions, in-depth interviews were conducted in order to focus on family history topics.

\section{Data Analysis}

Data were examined using qualitative content analysis as proposed by Caceres (2003). First of all, the communication model was selected. That led the researchers to consider the attributions made by women in connection to the exercise of violence against them by their partners. Secondly, previous analysis was developed when corpus of analysis was identified inside the transcription of in-depth interviews, including the autobiographies of women participants. The definition of the units of analysis in transcribing interviews and autobiographies was performed by assigning color codes corresponding to predetermined categories of analysis. Finally, the findings were synthesized.

\section{Results}

Main causes attributed to violence by partners in the group of women are psychological disorders, physiological problems, the learning process in the family of origin, the consumption of alcohol, social lying rained Machismo, and intolerance to the difficulties of everyday life (see Table 1). 
Table 1

\section{Attribution of Causes}

\begin{tabular}{|c|c|}
\hline \multicolumn{2}{|c|}{$\begin{array}{l}\text { Causes attributed to intimate partner violence: women tend to attribute reasons of external nature and beyond the control of man } \\
\text { such as: }\end{array}$} \\
\hline Consumption of alcohol & $\begin{array}{l}\text { "When he got drunk I was usually forced to have sex with him. I felt dirty because it is } \\
\text { something I do not want to do. Then, he got rid of me as he realized there is no worth in of } \\
\text { me". } \\
\text { "My partner began to drink. Then, he treated me badly, beat me, got jealous, once treated } \\
\text { me with a knife and finally humiliated me. On one occasion he dared to hang me, produced } \\
\text { injuries on me that made me incapable for walking. This is my experiences with him along } \\
\text { the years". } \\
\text { "Violence appears when he is drunk. He is a heavy drinker and that is a situation he does } \\
\text { not understand. That is the reason from which we have problems. In the end, everything } \\
\text { may be solved". }\end{array}$ \\
\hline Family learning source & $\begin{array}{l}\text { "Practically he grew up alone, without direction from anyone and no restriction at all. That } \\
\text { is why he does not know how to treat and respect women". } \\
\text { "The same thing occurs with my in-laws in terms of violence. For instance, my husband } \\
\text { was hit with an electric cable up to he was } 18 \text {. His mother, who was pregnant } 20 \text { times, also } \\
\text { beat him a lot". }\end{array}$ \\
\hline Machismo & "I think he inherited his father's behavior as it is the same in the case of his brothers". \\
\hline Psychological disorders & $\begin{array}{l}\text { "The point here is that he believes he is a macho in the way he thinks, as well as he also } \\
\text { dominates and commands females as per their inferiority condition". }\end{array}$ \\
\hline Physiological problems & $\begin{array}{l}\text { "Probably, my husband suffers from schizoid personality and obsessive compulsive } \\
\text { disorder symptoms (such as constant hand washing, checking plates, cups and cutlery, not } \\
\text { touching and disinfecting handrails or knobs that are touched by other people and avoiding } \\
\text { crowds). He also suffers from depression with symptoms including a low sexual desire, } \\
\text { insomnia and apathy, among others. When he was a child, he suffered selective mutism, as I } \\
\text { have been told". } \\
\text { "He had been and still is a very nervous person, bearing a problem brought from his } \\
\text { childhood whereas rejection from children caused him a great amount of stress". } \\
\text { "He is } 54 \text { now and I am } 41 \text { years old. During the last days I have considered the fact that } \\
\text { ropause is a valid cause of the situation, and wondered that this is me in my need for an } \\
\text { explanation for everything that happens between us". } \\
\text { "The point here is that he is sexist in the way he thinks and due to his need to control the } \\
\text { relationship". }\end{array}$ \\
\hline Problems in everyday & $\begin{array}{l}\text { "Daily life is what changes his mood. Luis faces so many problems at work and we do not } \\
\text { have enough money to cover our expenses". }\end{array}$ \\
\hline
\end{tabular}

Moreover, it can be observed that the reasons include failures in complying with established gender roles and interference of the family of origin which detonate violence (see Table 2).

\section{Discussion of Results}

As in the same case of the National Family Violence Survey (INSP, 2003) contained in this study, main violence causes include the consumption of alcohol, machismo, the learning of violent behavior in the family of origin, as well as certain psychological disorders. In particular, the consumption of alcohol seems to be one of the most representative reasons of violence in women provoked by their partners (M. Uribe \& P. Uribe, 1990), since alcohol symptoms led to irresponsible behavior in drinkers, thus legitimizing violence in women (Glantz, Martinez, Tinoco, \& León, 2004).

In addition to this, women report that they are abused by their partners as per the belief of being mistreated, a socially approved gender approach shared by women (Hamel, Desmarais, \& Nicholls, 2007). In particular, it is noted that the patriarchal culture is still a reason to legitimize violence and that idea continues along the time under a rigid family structure (Lozano, Castro, \& Moreno, 2008). Moreover, the fact that women knew that 
their partners had been physically abused during their childhood by their parents and that husbands became used to such violent environment, somehow justifies the exercise of violence against them, taking into consideration that violence suffered by their partners continues in their own intimate relationships. In general, the aspects mentioned above correspond to what Miracco et al. (2010) termed dysfunctional coping strategies to violence, since women usually justify such conduct with argument like "the way he is", "he suffered too much when he lived with his family", or "he is a heavy drinker". In the end, these ideas erroneously minimize dangers and risks associated with violence.

Table 2

Attribution of Reasons

Reasons attributed to intimate partner violence refer to conscious intentions and willingness to abuse and discipline women, such as:

Failure to meet the social expectations of

the female role (obedience, compliance

"I decided not to ask for his permission when I wanted to stay at my mother's, for what he denied my right to choose and forced me to do what he decided to. My husband grabbed me by my hair to bring me back and then lock me in our home".

with house work and dependence)

"The usual trigger for all these problems is that dinner is not ready at the right time for him, our house is not properly clean or due to any expression I made against him as my partner does not like to be contradicted on anything".

"I feel he was very angry because I never gave up being self-sufficient".

"His mother slowly started to get into our relationship, especially when we went to live with his family. She decided on the meals to cook. If I dare to prepare meals, my in-laws do not ate or express disgust, including Hector, my husband. Despite my opposition, I have been usually insulted and then disapproved by Hector. My The family of origin as a trigger for mother-in-law decided on everything, including my daughter's education and the $\begin{array}{ll}\text { aggression } & \begin{array}{l}\text { time for having breakfast and dinner. My husband used to compare me with his } \\ \text { mother by saying: "you should thank my mother for being living with us. You ought }\end{array}\end{array}$ to be like her and learn".

"He was being influenced by his parents and began to do what he was told and asked to do. He handed again the reins of his life to them. They interfered in everything including our intimate, social and family life. For instance, my in-laws advise Paloma, my daughter, against me".

The results of this study are also consistent with those found by Lozano et al. (2008). Here, women tend to attribute violence against them by their partners to situational factors such as the difficult economic context, problems at work, or stressful situations of everyday life. These results could be related to the hypothesis proposed by Hotaling (1988) who stated that women that live in situations of violence tend to assign responsibility to the situation as directly blaming partners would not let them justify why they continue to stay living with an abusive partner.

Efforts deployed by females in order to find a right name for those psychological disorders slinked to the personality are highly important to take into consideration. Also, identifying physiological problems as in the case of ropause is a matter hard to perform. Both tasks require search, read, and specialist consultation, as indicated by Lorente (2001) in an effort to explain the unexplainable as women say, or is this really a need for an explanation for everything that happens? Moreover, the allocation of these causes related to abuse seems to remove much of the responsibility to their partner who exercises violence on women due to the false belief that this kind of problems may eventually be solved by means of goodwill and violent behavior eliminated from time to time.

On the contrary, there are clear intentions of violence that are identified as originators. Among them, men hold the right to exercise disciplinary mechanisms on women. These are aimed at channeling, imposing, or 
punishing certain behaviors that go against the expectations of "femininity" (i.e., perform housework, make decisions, have a job, or even earn a higher income). In the end, there is a tacit agreement between the couple in which the male can exercise unrestricted power and his will on his partner (Jelin, 1991). In this regard, the study shows feelings of self-incrimination as described by Polo, López, Olivares, Escudero, Rodriguez, and Fernandez (2006) when people face traumatic events such as the case of the attacks. These authors found in women that self-incrimination is frequent and on the part of women is common in cases of intimate partner violence, although. However, the authors take into consideration the contributions of Janoff (1979) to classify such self-incrimination in terms of character or behavior. If self-incrimination is of characterial nature, it refers to the attribution of bearing a stable quality where women are likely to be assaulted by their partners (i.e., tendency to make independent decisions or seek self-sufficiency). On the other hand, the behavioral type involves specific controllable actions and events of negative nature (i.e., do light housekeeping or not have meals ready when partner requests).

It is important to underscore the characteristics of the reasons shown by this group of women, since the family of origin of the partner is important in the motivation process. Women interviewed talk about the interference of certain partner's relatives as important supporters of conflict in exchange of control in the household that they share with the couple (INSP, 2003). Commonly, in-laws include the mother, father, and sisters figures, who exercise power when they express moral judgments about the woman as they consider she does not meet their expectations as a new member of the family, in addition to the poor performance as a housewife. The woman is then devalued and this produces two aspects of violence. The first perspective identifies that the man justifies beating as a way to "support" his wife for her low performance and devaluation. The second perspective of abuse is linked directly to the own woman's acceptance of violence over her.

As a matter of conclusion, it can be established that the way how women process and explain the violent behavior of their partners apparently plays an important role for their decision to continue living together with them after the conflict. In addition, it can be said that women seek an explanation for both their partners' behavior and the conflict itself. In connection with the reasons of such perceived violence caused by partners, a certain degree of tolerance is found, as well as how violence is justified from a tacit and explicit way of perception.

\section{References}

Babcock, J. C., Jacobson, N. J., Gottman, J. M., \& Yerington, T. P. (2000). Attachment, emotional regulation and the function of marital violence: Differences between secure, preoccupied and dismissing violent and nonviolent husband. Journal of Family Violence, 15(4), 391-409.

Caceres, P. (2003). Content analysis: A methodological alternative attainable. Perspectives, II(1), 53-81.

Glantz, N. M., Martinez, I., Tinoco, R., \& Leon, P. (2004). "If he do not drink...": Alcohol consumption and its role in relationships. Mental Health, 27(6), 50-56.

Hamel, J., Desmarais, S., \& Nicholls, T. (2007). Perceptions of motives in intimate partner violence: Expressive versus coercitive violence. Violence and Victims, 22(5), 563-576.

Hotaling, G. T. (1988). Coping with family violence: Research and policy perspectives. New York: Sage Publications.

INSP. (2003). National survey on violence against women. Cuernavaca, Mexico: National Institute of Public Health.

INSP. (2006). National survey on violence against women. Cuernavaca, Mexico: National Institute of Public Health.

Janoff, R. (1979). Character logical versus behavioral self-blame: Inquiries into depression and rape. Journal of Personality and Social Psychology, 37(10), 1798-1809.

Jelin, E. (1991). Family, household and gender relation in Latin American. London: UNESCO.

Lorente, M. (2001). My husband beats me normal. Spain: Ares and Mares. 
Lozano, L. C., Castro, A. M., \& Moreno, J. H. (2008). Attributional styles on intimate partner violence in a battered women's group of the Bogota City. Psicogente, 11(20), 122-133.

Miracco, M. C., Rutsztein, G., Lievendag, L., Arana, F. G., Scappatura, M. L., Elizathe, L., \& Keengan, E. (2010). Coping strategies in battered women: The perception of the process by women. Research Yearbook School of Psychology, XVII, 59-67.

Polo, C., Lopez, M., Olivares, D., Squire, A., Rodriguez, B., \& Fernandez, A. (2006). Self-incrimination in women who are abused by their partners: Factors involved. Journal of the Spanish Association of Neuropsychiatry, XXVI(97), 71-86.

Richie, B. (1996). Compelled to crime: The gender entrapment of battered black women. New York: Routledge.

Uribe, M., \& Uribe, P. (1990). Violence: The unthinkable, the unthought. Bogota: The House of Women.

World Health Organization. (2002). Violence against women. Washington: Health and Development Division. 